\title{
INTERPRETING EXODUS FROM THE PERSPECTIVE OF NGONI NARRATIVES CONCERNING ORIGINS
}

\author{
Edwin Zulu \\ Justo Mwale Theological College \\ Lusaka, Zambia \\ Guest Lecturer, Stellenbosch University
}

\begin{abstract}
For many years now the interpretation of the Old Testament in Africa has been challenged by the context(s) of the readers. It has become apparent that the Old Testament text is better read and interpreted within a specific context. The Exodus story brings about new meanings when interpreted within a specific context, which influences their understanding of the Exodus narratives. In this paper, it is argued that interpreting the Exodus narratives from a Ngoni perspective concerning origins brings about wider understanding, also of the Exodus story, as it creates parallels and challenges the readers - Ngoni in this instance - to identify with the story, critique the story and live it.
\end{abstract}

Key words: Book of Exodus, Comparative Interpretation, Origin Narratives, Ngoni

\section{Introduction}

The theme of the OTTSA with its emphasis on the Old Testament in Africa is timely. It is timely in that Old Testament scholarship in Africa has made a significant contribution to the interpretation of the Hebrew Bible in specific contexts. ${ }^{1}$ It is also timely that we can look at the narratives and their significance on African society. They have added value to African religion. ${ }^{2}$ Africa has greatly appreciated narratives of various nature as vehicles of communication, motivation and instruction in morals and life.

The book under discussion, Exodus, contains narratives of the origins of a nation and their didactical content has been helpful in a society which shares parallel stories of origins. For example, the Ngoni of Zambia.

There are three perspectives from which the Ngoni narratives have been given: The colonial perspective, the missionary perspective and the indigenous people perspective. All these perspectives project a specific worldview informed by their local context(s).

This paper therefore, will want to argue that Ngoni narratives concerning origins creates interesting parallels with the Exodus narratives. The Ngoni, just like Israel, is a tribe that was emerging from a conflict situation and running away from a monarch that was not conducive to peace and development.

These parallels are similar to the Exodus narratives in which we see Israel coming out of the oppression under Pharaoh and being led by God, miraculously crossing the Red Sea.

\footnotetext{
See Holter, K 2004. Old Testament Research for Africa: a critical analysis and annotated bibliography of African Old Testament Dissertations, 1997-2000.

2 This is despite the fact that many narratives of European adventures, experiences and contacts with Africa, as well as inquiries about it, denied the existence of a religion of its own (Lugira 2000:2).
} 
Therefore, people understand the Exodus event in a new way in whose context(s) they have parallel experiences like the Ngoni people of Southern Africa. These are the perspectives from which Ngoni read the Exodus narratives, critique the story, interpret them and live them.

\section{Ngoni Narratives of Origins}

To begin with, it needs to be said that there are three perspectives:

- Firstly, there is a narrative that was written from the missionary perspective that had contacts with the Ngoni and wrote about them. Usually these wrote stories with some religious interpretations (Cronje 1982; Verstraelen-Gilhuis 1982).

- Secondly, narratives were written from the Colonial perspective, these were Government officials who had contacts with the Ngoni. They consequently wrote from the perspectives of their governments. This explains as to why the colonial records make mention of a number of wars between the Ngoni and British. For example, they interpreted the Ngoni as a warrior group, cruel and brutal.

- Lastly, the Ngoni themselves have written about their experiences with missionaries and colonial governments.

The description of the Ngoni in this paper takes into consideration the three perspectives.

The Ngoni tribe ${ }^{3}$ traces its origins from South Africa Kwa Zulu. Historians indicate that during the $17^{\text {th }}$ century there was wars of dispersal in the Zulu nation commonly known as Mfecane. King Shaka of the Zulus engaged in warfare destroying and defeating surrounding tribes. ${ }^{4}$ Many groups left Zululand going up north led by various tribal leaders. One of the leaders, Zwangendaba, led a group through Zimbabwe to Zambia before proceeding to Tanzania via Malawi. Zwangendaba crossed the Zambezi River at Zumbo on 19 November 1835 (Cronjé 1982:135). The significance of this crossing was that there was an eclipse of the sun. The Ngoni throughout their history have always seen this event as an act of God.

One of his sons, Mpezeni, who was later to lead a group back into Zambia was at the time a small child (Cronjé 1982:185). Zwangendaba led the group up to the shores of Lake Tanganyika where they defeated the Fipa tribe. After the death of Zwangendaba in 1848 at the southern tip of Lake Tanganyika there were succession disputes and the Ngoni dispersed in to different groups (Kishindo 2002:206).

One group led by Mpezeni finally settled in the eastern part of Zambia (VerstraelenGilhuis 1982: 42).

The Ngoni is related to the modern Zulu and Swazi tribes of Southern Africa ${ }^{5}$ and as they migrated up north during the Mfecane wars they adopted military skills similar to the Zulu.

The Ngoni, in 1897, under the leadership of Nsingo, the elder son of the chief Mpezeni, led a rebellion against the British settlers (Baxter 1950:14). ${ }^{6}$ The British army crushed the

The Ngoni are found today in the following places: Malawi Districts of Mzimba, Dowa, Fort Manning Dedza and Ncheu, In Zambia they are found in the Chipata and Lundazi districts and also some parts of Mozambique and Tanzania, Lake Tanganyika territory.

4 The immediate cause of their departure was that Shaka defeated Chief Zwidi Chief of the Ndandwe people. As part of the Zwidi people the Ngoni did not want to stay under Shaka They trekked north (Read 1936:454).

5 The organisation of the Ngoni army was similar to the Zulus. All regiments were organised according to age groups. The Mafera recruits were undergoing training and not ready for war. Maora, Mahema and Mandandaused headgear, Madjinga were old soldiers who did not go out for war. Each of these groups attacked separately allowing a spirit of competition (Baxter 1950:23). 
rebellion when the leader of the uprising, Nsingo, was captured and executed (Baxter1950: 21). This ended the rebellion among the Ngoni.

\section{Christianity among the Ngoni}

The Ngoni were a religious people and believed in the works of God, Unkhulukhulu. A number of rites and rituals was created to pay homage to their God such as Ncwala. God among the Ngoni was a fair God who was working through the ancestors to bring about the whole concept of the ancestor veneration among the Ngoni, which forms part of a complex worldview.

Given their militant nature, the Ngoni were resistant to the Gospel. It was only after many years of evangelistic attempts that Christianity was introduced to the Ngoni through work of the Dutch Reformed Church. Around 1900 an evangelist was sent from Malawi to speak to the Chief Mpezeni. The first mission station was established in 1903 at Madzimoyo and still remains to this day the major mission station of the Reformed Church in Zambia.

\section{Summary of Ngoni Narratives Concerning Origins}

- Running away from oppression from King Shaka of the Zulu.

- Sojourner motif - they travelled from South Africa through Zimbabwe, Zambia, Malawi and Tanzania and back into Zambia to the present day Chipata.

- Warrior character of the tribe fought its way through the region; presumably with God's help.

- Crossing of the Zambezi River in 1838 during an eclipse of the sun seen as an act of God.

- Religious character of the tribe remained with them throughout their journeys, i.e. one of the ceremonies to thank God for the good harvest $N^{\prime} c w a l a$, which has been maintained to this day. This symbolises the Ngoni's continued allegiance to their God.

- Solidarity with the suffering. It did not make the Ngoni to be supreme or peculiar. The experiences brought among them a sense of identity and ideological nuances.

\section{Interpreting Exodus Narratives ${ }^{7}$}

There are many problems associated with the book of Exodus. These problems are varied in their magnitude.

- Firstly, the major difficulty is that Egyptian records make no mention of the Exodus.

6 There are many reasons given for the reasons of the rebellion. From the colonial perspective, the Ngoni, as a strong tribe, was a threat to their advancement in the region. On the other hand, the missionary perspective depicted that the militant Ngoni needed to be subdued so that the Gospel could be propagated. The indigenous people saw the cause of the rebellion as an uprising against the colonial power who was claiming indigenous land and displacing people in the region.

7 There have been on going debates on the historicity of the Exodus. See Propp, W 1999. Exodus: A New Translation. Anchor Bible; Double Day; Freirichs, E \& Lesko, L 1997(ed.) Exodus: the Egyptian evidence. Eisenbrauns, Hoffmeier, JK1996. Israel in Egypt: the evidence for the authenticity of the Exodus Tradition. Oxford Press. 
- Secondly, archaeological evidence has found no direct evidence to corroborate the biblical account.

- Thirdly, inscriptions from ancient Egypt contain no mention of Hebrew slaves or the devastating plagues nether the destruction of Pharaoh's army.

- Fourthly, the person of Moses is also questioned as to whether he was a real person or a fictitious one.

The problematic question of the historicity of the narratives of the book of Exodus has been much discussed by many scholars. ${ }^{8}$ The issues raised continue to be part of the on going research.

Durham (1987:XXV) needs to be taken seriously. He argues that we cannot do without more specific dates than we have. It is not possible to provide historical confirmation for anything or anybody mentioned in the book of Exodus. Therefore, by any case the historical critical issues should not blur the meaning of the final text (Durham 1987:XXVI).

The important thing is to receive the book of Exodus as it has been given, which means studying it as a complete story (Ryken 2002:17). In addition, it needs to be understood in the context of the whole Pentateuch (Sarna 1992.694).

With no doubt at all, the book of Exodus is a significant narrative in the lives of the Israelites. It is a story that defined their existence, identity and an act of God' redemption (Ryken 2002:17). In addition, the narrative is crucial to the Christian faith. It is important to take cognisance of the fact that the book could not have been written at a single sitting. Some materials might have been orally transmitted before being incorporated into the book as we have it today.

\section{The Exodus Narrative in its Canonical Context}

The Biblical narrative starts with the descendants of Jacob (Ex.1: 1-5, Gen. 46:8-27). Joseph was already in Egypt. The Israelites entered Egypt due to the fact that at a time his brothers sold Joseph into slavery and he eventually became a prince in Egypt. Later the whole family ended in Egypt. After the death of Joseph, the Israelites became slaves of the Egyptians (Ryken 2002:25). Hence the story starts with the Israelites being a large group a nation living in bondage and cruel oppression (Dillard 1994:57).

\section{Significance of the Exodus Event}

It needs to be argued that despite the fact there are many problems associated with the book of Exodus, the narratives are a great story that speaks of the intervention of God in the lives of a suffering people in a miraculous way. It motivates, inspires and also has a didactic function.

- Origins were crucial in this regard as it was a common binding factor. The sojourner motif in a foreign land became the motivating factor. This explains as to why Exodus.1: 1-7 refers to their background already hinted in Gen. 46:1-27.

- Common identity urge was polemical and was crucial for survival - they had to maintain their religious, cultural and ideological identity to avoid extinction, i.e. even the efforts of Pharaoh to wipe out the generation by killing the first born could

8 Seters, J 1966. The Hykos: a new investigation. New Haven: Yale University Press, Rowley, and HH From Joseph to Joshua: Biblical tradition in the light of archeology. London: Oxford Press, Bimson, and JJ 1978. Redating the Exodus and conquest. JSOT sup. Sheffield: 
not be successful. A baby is born and put in hiding and miraculously this child (Moses) is brought up in the royal house (Ex. 2:1-10).

- The narratives of origins created a narrative of where they came from thereby creating a nationalistic attitude, i.e. Moses had to kill the Egyptian for the sake of his own people (Ex2: 11-22).

- In addition, it also created ideologies of who they were and ought to be (Book of covenant Ex. 21:1-23:33).

- The narratives of origins created hope for the future. The people were convinced that God was leading them to a future - they could live in Canaan.

- The story and characters, created inspiration among the Israelites. They were able to follow the leaders through out their long journey. The leadership of Moses becomes inspirational $(3: 1-4: 17)$.

\section{Parallels created in the Exodus Narratives and Ngoni Narratives}

- Common origins as a binding factor for the nation in conflict.

- Common identity as a survival strategy in the foreign land.

- Common origins became ideological and created nationalistic ideals; identification with the tribe.

- Leading characters in the narratives became sources of inspiration and motivation.

- Narratives became sources for the future direction of the tribe.

- Message in the narratives became basis for education as it had two functions: Illustrative and didactical.

\section{Summary and Conclusions}

- The Exodus narratives depict redemptive acts of God in a people. That these acts are varied, remains a great inspiration for many people.

For all that, the fact that the Exodus narratives have many problems, relates to the historicity of the whole matter.

- The Ngoni tribe has similar narratives of the redemptive acts of God. These narratives have given them motivation, identity and inspiration.

- Some parallels are created when Exodus narratives are interpreted in the context of Ngoni narratives concerning origins.

- The narratives must also have been analysed critically. Despite the parallels with the Ngoni and the Exodus story, the Ngoni cannot in any way identify themselves with the Bible, biblical incidents and characters without taking into consideration the cultural and religious differences. In addition, the Exodus story cannot in any way justify imperialistic attitudes, nor can it legitimise the supremacy of a single nation. In other words no attempt is made by the Ngoni claims to legitimise the narrative as a basis on which they could subdue other nations.

The narrative has many aspects that are part of the debate in this region, such as warfare, for example, Zambia is surrounded by the Great Lakes Region, which has always experienced wars. For this reason, it is paramount that any reinterpreting of the narrative by the Ngoni in no way justifies atrocities. 
Therefore, interpreting the Exodus narratives from the Ngoni perspective gives one a perspective from which the Exodus narratives can be interpreted, critiqued and applied in a cultural context such as Africa, thereby bringing out new meanings, which influence understanding of the narratives. In addition, a worldview of a specific people is important in any interpretative process (Zulu 1998:69).

Any attempt to bring home the Biblical message to African peoples should stress the encounter of the Biblical message and the rich religious heritage of Africa. This will make the indigenous people, like the Ngoni, find a framework within which they could identify themselves with the Biblical message of the narratives. Such an interpretation should not ignore the uniqueness of the Biblical narrative and context.

\section{BIBLIOGRAPHY}

Barnes, JA 1967. Politics in a changing society: A political history of the Fort Jameson Ngoni. Manchester: Manchester University Press.

Baxter, TW 1950. The Angoni Rebellion and Mpezeni. Northern Rhodesia Journal Vol. 11 p. $14-24$.

Bimson, JJ 1978. Redating the Exodus and conquest. Sheffield: JSOT.

Cronje, JM 1982. Born to Witness. Pretoria: NG Kerkboekhandel.

Dillard, RB \& Longman III, T 1994. An introduction to the Old Testament. Grand Rapids: Zondervan.

Durham, JI 1987. Exodus. Waco: Word.

Goldingay, J 1981. Approaches to Old Testament Interpretation. Leicester: Intervarsity.

Freirichs, E \& Lesko, L 1997 (ed.) Exodus: the Egyptian evidence. Eisenbrauns.

Hoffmeier, JK 1996. Israel in Egypt: The evidence for the authenticity of the Exodus Tradition. Oxford: OUP.

Holter, K 2004. Old Testament Research for Africa. New York: Peter Lang.

Lugira, AM 2000: Africism: A Geontological approach to African religion and Philosophy. Paper presented at the $26^{\text {th }}$ Annual Third World Conference.

Moberly, RWL 1992. The Old Testament of the Old Testament: Patriarchal narratives and Mosaic Yahwism. Minneapolis: Augsburg Fortress.

Morris, DR 1994. The washing of the spears: The rise and fall of the Zulu Nation. London: PIMLICO.

Niditch, S 1993. Folklore and the Hebrew Bible. Minneapolis: Fortress.

Pratt, RL 1990. He gave us stories. The Bible's student guide to interpret Old Testament Narratives: Brentwood: Wolgmuth \& Hyatt.

Propp, W 1999. Exodus: A New Translation (Anchor Bible). New York: Doubleday.

Read, M 1937. Songs of the Ngoni People. Bantu Studies Vol.11 p.10-35.

Read, M 1936. Tradition and Prestige among the Ngoni. Bantu Studies Vol. 9, P.453-484.

Rowley, HH 1971. From Joseph to Joshua: Biblical tradition in the light of archeology. London: Oxford Press.

Thompson, J 1994. The legacy of Donald Fraser. International Bulletin of Missionary Research Vol. 18 No.1. p. 32-35. 
Sarna, NH 1992. Exodus (Anchor Bible). New York: Doubleday.

Verstraelen-Gulhuis, G 1982. From Dutch Mission Church to Reformed Church in Zambia. Franeker: T Wever.

Winterbottom, JM 1950. Outline Histories of two Northern Rhodesian tribes. RhodesLivingstone Journal. No.9 p.14-25.

Young, TC 1930. Religion of my Fathers. International Review of Mission Vol. XIX p. 362-376.

Zulu, E 1997. A Ngoni assessment of the role of ancestors with in Ancient Israelite worldviews and religion in Genesis 11:28-50:26. Unpublished DTh dissertation. University of Stellenbosch, South Africa. 